\title{
THE SPATIAL DEVELOPMENT OF UNDEVELOPED REAL ESTATE IN THE WROCŁAW DISTRICT
}

\author{
Leszek Stanek ${ }^{1}$ \\ 1 Department of Spatial Economy, Wrocław University of Environmental and Life Sciences, Grunwaldzka 53 \\ Str., 50-357 Wrocław, Poland, e-mail: leszek.stanek@up.wroc.pl
}

Received: 2016.05.15

Accepted: 2016.08.08

Published: 2016.09.30

\begin{abstract}
The aim of the article is to analyse the problem of spatial planning in the Wrocław district, especially regarding the evaluation of the purpose of land in municipal studies of the conditions and directions of spatial development. The analysis of purpose is significant with respect to its impact on real estate value and the forming of the relation between supply and demand on the market. The purpose of land designated for various types of development and construction is decided by local administration and municipal councils. This, however, does not ensure adherence to principles of sustainable development, as showcased by summing up the methods of land allocation in the district. It has been determined that according to the status for the end of $2012,34 \%$ of land in the Wrocław district has been developed for housing, 26\% for services and $18 \%$ for economic activity.
\end{abstract}

Keywords: undeveloped real estate, land allocation, metropolitan area.

\section{INTRODUCTION}

Following the year 1990 land properties surrounding cities, especially those located within metropolitan areas have become subject to strong pressure towards investment. The majority of agricultural land they encompass has been repurposed for construction, i.e. housing, services, industry and communication. Such lands in the Wrocław district (WD) contain some of the most efficient and useful agricultural soil in Poland.

In accordance with article 14, section 1 of the Spatial Planning and Development Act (SPaDA) the purpose of land is determined through the use of the local spatial development plan (LSDP). However, since January 1, 2004, when the SpaDA came into force, the LSDPs no longer apply in most Polish areas. The purpose of property located in such areas is determined through municipal studies of the conditions and directions of spatial development (further referred to as "Studies"), since according to article 9, section 4 of the SPaDA their provisions "are binding to municipal authorities in the process of formulating local plans."
As of December 31, 2012 the areas in all 9 WD municipalities were regulated through Studies enacted between 2004-2012, which served as a basis for a uniform and reliable method of determining the purpose of land.

A detailed and precise analysis of the district's land properties is currently impossible due to a lack of up-to-date and complete data on:

- the possibilities for increasing development density in areas with purposes established in the LSDP;

- the decisions regarding the location of public purpose investments and the established development conditions, issued in cases where no LSDP were available in accordance with article 50, section 1 and article 59, section 1 of the SpaDa.

Article 154 of the Act on real estate management, as well as the professional experience of property appraisers prove the fact that the allocation of real estate has a direct impact on its value. 


\section{ANALYSIS OF LITERATURE}

Unlike in large European countries such as Germany, France and Great Britain, spatial planning in Poland at the level of the district is not obligatory and is thus non-existent.

Available case studies on the subject of the analyses of the correlates between the undeveloped property market and land purpose most commonly involve areas reduced to a number of separated municipalities [Zydroń, 2011]; [Kałmucka et al. 2012]. Other studies analyse property meant specifically for selected purposes [Siejka, 2011]; [Gawron, 2014], or provide general characteristics of lands being part of metropolitan areas [Bieda and Jasińska, 2010], [BRILAND Report, 2013]. One of the articles involves the lands in the district [Zydroń and Kaczmarek, 2012], yet contains only analyses of the changes in ownership and structures of use in relation to an evaluation of the proper use of agricultural land.

The above-mentioned studies make use of a limited scope of real estate market analyses and deal with the subject of the various types of purpose in a very simplified manner. At times they contain overgeneralised functional assumptions, e.g. regarding the qualification of areas meant for development [Zydron, 2011], which is contrary to Polish legal regulations.

Other studies, e.g. The real estate market within the spatial development system by professor Tadeusz Markowski provide a valid analysis of the problem in question yet study it on a larger scale and in a very general scope. They indicate the ideological propositions for purpose-driven actions towards improving spatial development but never delve into the details of practical problems tackled in this article.

\section{RESEARCH AREA AND METHODOLOGY}

The research area encompasses the Wrocław district, with an area of $1118 \mathrm{~km}^{2}$, populated in 2012 by 124,509 residents [Wrocław Statistical Office, 2016]. It includes 9 out of the 27 municipalities of the Wrocław Metropolitan Area (WMA) established in resolution XLVIII/1622/2014 by the Lower-Silesian Regional Assembly on March 27, 2014 which approved the 2020 Lower Silesia Voivodeship Spatial Development Plan.

Due to their spatial order and landscape values the district's areas should be subject to protec-

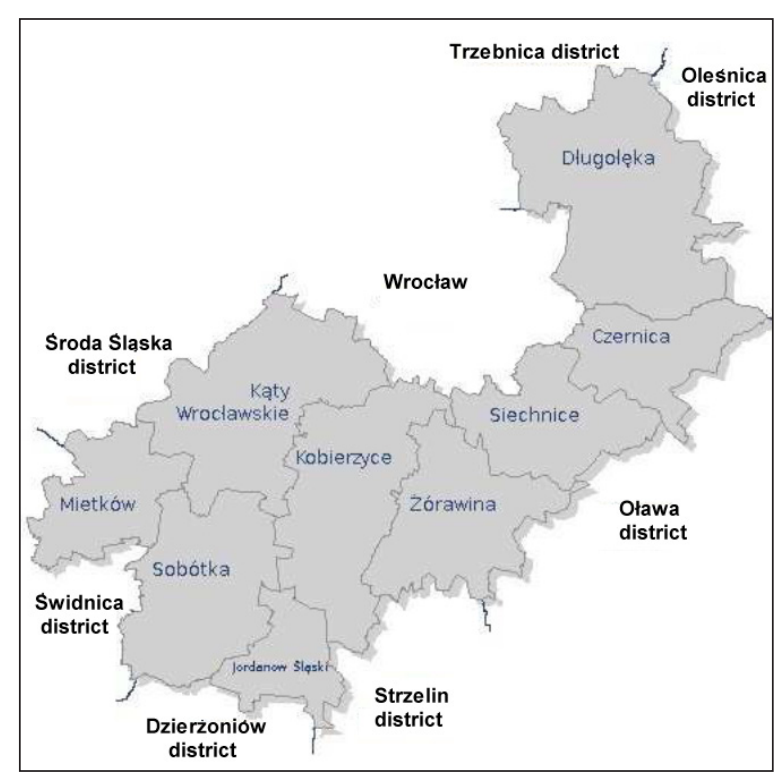

Figure 1. Map of the Wrocław district [The Wrocław District Development Strategy, 2012].

tion. These high attributes are a result of adhering to principles of sustainable development, high soil valuation classes and highly efficient agricultural economy made possible, e.g. due to beneficial climate conditions.

The following data served as the basis for the analysis:

1. Municipal studies of the conditions and directions of spatial development from the years 2004-2012;

2. Market transactions from the register of real estate prices and values retrieved from the District Cadastre Office in Wrocław.

3. Cadastre data comprised of vector maps with marked borders; plots, sections, municipalities, land use and soil valuation classes along with building outlines.

Ad 1. Since not all of the district's lands are subject to LSDPs, the analyses of purpose have been established on the basis of Studies enacted in all of its municipalities. More precise data has been attained through a vectorisation of the Studies, conducted on the basis of background drawings scanned in a 1:100000 scale. The boundaries of allocation have been aligned with plot borders and sections. The maps have been fixed to record parcel borders located on the outskirts of each municipality. The outline vectorisation has been performed with an accuracy allowing to determine the dominant functions for each plot. After fitting the map all the functional units of the Studies have been vectorised, focusing on three land 
purposes: agriculture (R), housing (M) and economic activity and services (AG, U, US).

Ad 2. The analysis of real estate prices and values has been conducted on the basis of a register made available by the District Cadastre Office in Wrocław, which included over 35,000 transactions from 2001 to March 2013. During the first stage all the items have been rearranged in a new transactions register. The process involved the merging of the elements of single transactions, with a calculation of the land areas-agricultural land, forest areas, developed area and otherpertaining to each transaction. The merging was achieved according to the following procedure:

- collecting all the elements which constitute the transaction, i.e. plots, plot shares, buildings, building shares and premises;

- determining the land area for housing areas, developed agricultural areas, roads, agricultural areas, areas used in services and for other purposes for each transaction using entries in the remarks sections and an analysis of land purpose within plots;

- determining the purpose of land formulated in the LSDP using entries in the remarks sections.

The quantitative analyses involved real estate transactions which have been executed in the "free market" and "tender sale" modes.

Ad 3. Since the district authorities did not collect complete cadastre data regarding buildings and premises the study's subject matter had to be limited to an analysis of undeveloped land property trade.

The analysis of undeveloped property prices in the Wrocław district between 2001-2012 was based on a division of transactions with respect to land allocation. The transactions have been separated into a number of undeveloped land groups:

- agricultural land considered by the purchaser as agricultural land;

- agricultural land considered by the purchaser as transitional agricultural land;

- land meant for housing;

- land meant for economic activity and services.

The lands in certain municipalities have also been divided into:

- land meant for homestead development;

- land meant for housing and services;

- land meant for recreation;

- land meant for landscape services.
The non-uniform manner of marking allocation makes it difficult to summarise the area of lands and their potential, which has its influence on shaping real estate prices.

The process of marking the allocation of a transaction in the remarks section of the price register as well as an analysis of documents and graphs included in the Studies served the process of qualifying transactions to a given group. Prior to the classification, the real estate markers used by the operator of the price register have been verified using a vectorised Study and a numeric cadastral map.

A software application has been developed for the purpose of verification, which allowed the calculation and proper marking of the set of plots located within each of the Studies' outlines. Each plot has been marked using the name of the Study outline it was part of as well as the percentage of its share within the outline.

Example: plot 022301_2.0005.599 has been marked as RZ91 ZL9. This means that it belongs in $91 \%$ to the RZ (green agricultural land) outline and in $9 \%$ to the ZL (forest area) outline. The Study markers have been assigned to every plot within the district's municipalities.

\section{SPATIAL ANALYSES}

The variability of land prices, dependent on land purpose, between 2001 and 2012 has been analysed separately for each of the 9 municipalities based on a division to three purpose groups:

1. Agricultural land for crops (the unit price usually does not exceed 10 PLN per $\mathrm{m}^{2}$ );

2. Agricultural land whose purpose is scheduled to change or land that is especially valuable (higher prices indicate other aims behind the purchase of the land than agriculture, e.g. using the option of changing the purposes established in the Studies or LSDP);

\section{Land for economic activity.}

Special attention was paid to an analysis of areas meant for housing and service-related development, as well as business activity, since these purposes limit the principles of supply and demand for areas with the highest prices in undeveloped land sale. The transaction prices of real estate for the day of the specified land allocation have been updated according to the following formula: 
Price_K $=$ Price_tr - Price_sr + Price_sr_K

where: Price_K $K$ is the updated price of the land for December 31, 2012;

Price_tr is the current price of the land on the day of the transaction;

Price_sr is the average price of the land on the day of the transaction;

Price_sr_K $K$ is the average price of the land from all transactions calculated for December 31, 2012.

The updated transaction prices have been assigned to record parcels in all sections and for all municipalities. These were used to establish transaction price distribution maps with the division to allocation zones for crops and agricultural land meant for non-agricultural purposes, housing development and economic activity.

On the scale of the Wrockaw district these maps for the purposes in question have been represented in a study entitled An analysis of the real estate market in the Wroctaw district [Lasota and Stanek, 2013].

\section{RESULTS OF THE STUDY}

The legal sovereignty granted to municipalities in the domain of spatial development has led to a poorly controlled, exploitative management of space. The analysis [Lasota and Stanek, 2013] shows a case of 9 Studies for the WD municipalities where there has been an increase in the total area meant for the purposes of a variety of de- velopment types that was disproportionate to the actual needs.

- 17426.4759 ha of land has been designated for single-family housing, 6001.2832 ha of which $(34.4 \%)$ has already been developed. Assuming that a house meant for 4 persons can be founded on a plot of an area of $700 \mathrm{~m}^{2}$, it is possible to create a total of 163,217 buildings on the non-developed lands designated for housing, which would provide residence to 652,868 people, which is more than the number of currently registered permanent residents in Wrocław (633,802 people).

- 9195.4563 ha has been designated for business activity, $18 \%$ of which has already been developed.

- 2560.6574 ha has been designated for services, with 26\% already developed in 2013.

The current Studies have been enacted for the Wrocław district between 2005-2012. In some sections the transactions from 2001-2012 have been settled on the basis of prior land allocation. Some of these transactions, especially those with agricultural land prices significantly divergent from average values, have most likely been performed using Studies which the seller and the purchaser had access to, but which have not yet been enacted. Proper land economy and reliable land evaluation requires the district's County Office to have access to vectorised local plans or Studies.

The manner of defining purpose and marking land in municipal studies of the conditions and directions of spatial development requires

Table 1. Use of land for housing development purposes (MM).

\begin{tabular}{|c|c|c|c|c|}
\hline Municipality & Area for MM & Developed area for MM & Area of buildings on lands for MM & Use \\
\hline & ha & ha & square metres & $\%$ \\
\hline Czernica & 2771.2749 & 714.7171 & 727934 & 26 \\
\hline Długołęka & 2826.7787 & 1226.9995 & 1332418 & 43 \\
\hline Jordanów & 654.5839 & 225.4062 & 208935 & 34 \\
\hline The town of Kąty & 191.3056 & 98.9171 & 177830 & 52 \\
\hline Kąty Municipality & 3245.6536 & 958.1860 & 962511 & 30 \\
\hline Kobierzyce & 1183.6636 & 617.8614 & 835984 & 52 \\
\hline Mietków & 384.0914 & 238.4046 & 247527 & 62 \\
\hline The town of Sobótka & 421.9062 & 139.7763 & 170812 & 33 \\
\hline Sobótka Municipality & 1582.3089 & 463.7624 & 432848 & 29 \\
\hline $\begin{array}{l}\text { The town of } \\
\text { Siechnice }\end{array}$ & 275.5796 & 93.0994 & 133643 & 34 \\
\hline $\begin{array}{l}\text { Siechnice } \\
\text { Municipality }\end{array}$ & 1939.8764 & 692.9577 & 683720 & 36 \\
\hline Żórawina & 1949.4531 & 531.1955 & 571697 & 27 \\
\hline Wrocław district & 17426.4759 & 6001.2832 & 6485859 & 34 \\
\hline
\end{tabular}


Table 2. Use of land for economic activity purposes (AG).

\begin{tabular}{|l|c|c|c|c|}
\hline \multicolumn{1}{|c|}{ Municipality } & Area for AG & Developed area for AG & Area of buildings on lands for AG & Use \\
\hline ha & 771.6289 & ha & square metres & \% \\
\hline Długołęka & 1473.7276 & 295.7648 & 3688685 & 20 \\
\hline Jordanów & 351.3302 & 59.1189 & 35555 & 17 \\
\hline The town of Kąty & 304.6299 & 87.3845 & 138962 & 29 \\
\hline Kąty Municipality & 1772.8232 & 262.4614 & 223375 & 15 \\
\hline Kobierzyce & 2201.8642 & 498.5000 & 991807 & 23 \\
\hline Mietków & 188.7802 & 37.5644 & 23033 & 20 \\
\hline $\begin{array}{l}\text { The town of } \\
\text { Sobótka }\end{array}$ & 160.2655 & 99.4477 & 38834 & 62 \\
\hline $\begin{array}{l}\text { Sobótka } \\
\text { Municipality }\end{array}$ & 586.2875 & 26.8802 & 32895 & 5 \\
\hline $\begin{array}{l}\text { The town of } \\
\text { Siechnice }\end{array}$ & 266.4809 & 134.4463 & 118080 & 50 \\
\hline $\begin{array}{l}\text { Siechnice } \\
\text { Municipality }\end{array}$ & 749.2264 & 53.7783 & 78549 & 7 \\
\hline Żórawina & 368.4118 & 34.2641 & 61882 & 9 \\
\hline Wrocław district & 9195.4563 & 1647.5802 & 2152442 & 18 \\
\hline
\end{tabular}

standardisation and uniformisation. This can be achieved by enforcing the manner of land marking provided in appendix 1 of the regulation by the Minister of Infrastructure from the Dz.U.2003.164.1587 (Journal of Laws). This solution is currently not provided for by the regulation of the Minister of Infrastructure from Dz.U.2004.118.1233. The problem of uniformising Study markers is also avoided in the 2020 Lower Silesia Voivodeship Spatial Development Plan, even in the delineated WMA area.
The accuracy of analytical calculations would be improved by altering article 5 , section 1 of the regulation by the Minister of Infrastructure from Dz.U.2004.118.1233, so that it would establish the option of executing the Study using a modified copy of the master map instead of a copy of the topographic map. This would additionally allow to more precisely determine the congruence of the LSDP with the provisions of the Study, described in article 14, section 5 of the Act on spatial planning and development.

Table 3. Use of land for services (US).

\begin{tabular}{|l|c|c|c|c|}
\hline \multicolumn{1}{|c|}{ Municipality } & Area for US & Developed area for US & Area of buildings on lands for US & Use \\
\hline ha & ha & square metres & $\%$ \\
\hline Długołęka & 216.359 .6226 & 19.84008 & 25560 & 8 \\
\hline Jordanów & 114.7335 & 15.3593 & 26031 & 13 \\
\hline The town of Kąty & 81.9554 & 49.5294 & 22328 & 60 \\
\hline Kąty Municipality & 148.8736 & 17.3977 & 8980 & 12 \\
\hline Kobierzyce & 377.0824 & 194.1575 & 291046 & 51 \\
\hline Mietków & 59.7606 & 16.8798 & 20526 & 28 \\
\hline $\begin{array}{l}\text { The town of } \\
\text { Sobótka }\end{array}$ & 227.9203 & 74.2034 & 71700 & 33 \\
\hline $\begin{array}{l}\text { Sobótka } \\
\text { Municipality }\end{array}$ & 279.1308 & 41.6706 & 8663 & 15 \\
\hline $\begin{array}{l}\text { The town of } \\
\text { Siechnice }\end{array}$ & 79.8863 & 15.6757 & 27065 & 20 \\
\hline $\begin{array}{l}\text { Siechnice } \\
\text { Municipality }\end{array}$ & 264.1082 & 101.82 & 62470 & 39 \\
\hline Żórawina & 317.2239 & 84.0767 & 94735 & 27 \\
\hline Wrocław district & 2560.6574 & 6610087 & 677363 & 26 \\
\hline
\end{tabular}




\section{CONCLUSIONS}

The analysis of the register of real estate prices and values indicated that the registers are kept in accordance with the currently enforced regulation on registering land and property. Unfortunately, the land allocations from the LSDP or the Studies, applying at the time of the transaction are not registered for each transaction. Adhering to the requirement of registering land allocation will make future analyses of transaction prices in each area easier without the need for additional corrections. Study guidelines can be added to the cadaster in a form of additional data for each record parcel, along with full data regarding the components of the real estate.

Analyses of municipal and district land trade can be automated once the prices and value register has been verified or once representative real estate has been selected. After establishing the complete registration of buildings and premises the analytical process can be broadened by the addition of premise and building trade analyses. Currently, such analyses would be subject to simplification and would prove hardly useful for municipal authorities and property appraisers.

The analysis indicated the need to introduce corrections to cadastral maps, as plot borders and land outlines include unassigned enclaves which make it difficult to perform spatial analyses and precisely determine land purpose.

\section{REFERENCES}

1. Bieda A., Jasińska E. 2010. An analysis of the real estate market in former rural areas using the example of the Kraków agglomeration (in Polich). Infrastruktura i ekologia terenów wiejskich - The infrastructure and ecology of rural areas, $12,5-15$.

2. Gawron H. 2014. The development of urban agglomerations and their significance for the development of the local real estate market (in Polich). Zarządzanie i Finanse - Management and Finances, 12(4).

3. Kałmucka W., Kałmucki K., Kamińska A. \& Filipek A. 2012. The changes in land use in Lublin and its closest vicinity in the last 40 years (in Polich). Barometr Regionalny - Regional Barometer, 4(30).

4. Markowski T.. 2015. Rynek nieruchomości w systemie planowania przestrzennego (The real estate market in the spatial planning system). Doradca Rynku Nieruchomości - Real Estate Market Adviser, 2.

5. BRILAND Report 2013. An analysis of the prices of land and the investment potential in the Warsaw metropolis (in Polich). BRILAND, Warsaw, Al. Jerozolimskie $96 \mathrm{Str}$.

6. Siejka M. 2011. An analysis of the agricultural real estate market using the example of the rural areas of the Kraków district municipalities (in Polich). Infrastruktura i ekologia terenów wiejskich - The infrastructure and ecology of rural areas, 3, 265-273.

7. Zydroń A. 2011. An analysis of the undeveloped real estate market in the selected municipalities of the Greater Poland region (in Polich). Rocznik Ochrona Środowiska - Environmental Protection Yearly, 13, 2033-2048.

8. Zydroń A., Kaczmarek J. 2012. An evaluation of the structural changes in the use and ownership of land in the years 2003-2010 in municipalities of the Środa Śląska district (in Polich). Nauka Przyroda Technologie - Science Nature Technologies. Poznań University of Life Sciences, 6/2, 1-12.

9. Lasota T., Stanek L. 2013. An analysis of the real estate market in the Wrocław district (in Polich). http://www.wrosip.pl/dokumenty/Analiza $\% 20$ rynku $\% 20$ nieruchomo $\% \mathrm{C} 5 \% 9 \mathrm{Bci} \% 20 \mathrm{w} \% 20 \mathrm{Pow}-$ iecie $\% 20$ Wroc $\%$ C5\%82awskim.pdf.

10. Act from March 27, 2003 on spatial planning and development (consolidated text, Dz.U.2015.199 as amended).

11. Act from August 21, 1997 on real estate economy (consolidated text, Dz.U.2015.1774 as amended).

12. Regulation by the Minister of Regional Development and Construction from March 29, 2001 regarding land and property registration (consolidated text, Dz.U.2015.542).

13. Regulation by the Minister of Infrastructure from August 26, 2003 regarding the required scop of the local spatial development plan project (Dz.U.2003.164.1587), p. 6-7.

14. Regulation by the Minister of Infrastructure from April 28, 2004 regarding the scope of the municipal conditions and directions of spatial development project (Dz.U.2004.118.1233).

15. (2012). The Wrocław District Development Strategy for 2012-2020. (retrieved on May 1,2016) http:// powiatwroclawski.ibip.wroc.pl/public/?id=98046.

16. Wrocław Statistical Office (data retrieved on February 29, 2016).

17. http://stat.gov.pl/vademecum/vademecum_dolnoslaskie/portrety_powiatow/powiat_wroclawski.pdf. 